Published by Al-Nahrain College of Medicine P-ISSN 1681-6579

E-ISSN 2224-4719

Email: iraqijms@colmed-alnahrain.edu.iq

http://www.colmed-alnahrain.edu.iq

http://www.iraqijms.net

Iraqi JMS 2020; Vol. 18(2)

\title{
Opportunistic Viral Infections After Kidney Transplantation: A Review
}

\author{
Asmaa B. Al-Obaidi ${ }^{1}$ PhD, Mervit B. Jasim MSc, Mustafa R. Hussein ${ }^{2}$ FICMS, \\ Haider S. Kadhim ${ }^{1} P h D$, Manal A Habib ${ }^{3} P h D$ \\ ${ }^{1}$ Dept. of Microbiology, College of Medicine, Al-Nahrain University, Baghdad, Iraq, ${ }^{2}$ Baghdad Teaching Hospital, Baghdad, Iraq, \\ ${ }^{3}$ Dept. of Pathology, College of Medicine, University of Baghdad, Baghdad, Iraq
}

\begin{abstract}
Keywords kidney transplantation, viral infections

List of abbreviations: $A D V=$ Adenovirus, $B K V=B K$ polyomavirus, $\mathrm{BKVN}=\mathrm{BK}$ virus nephropathy, $\mathrm{CMV}=$ Cytomegalovirus, $\mathrm{EBV}=$ Epstein-Barr virus, $\mathrm{HHV}=$ Human herpes virus, $\mathrm{JCV}=\mathrm{JC}$ polyomavirus, PTLD = Post-transplant lympho-proliferative disorder, RTR $=$ Renal transplantation recipients VZV = Varicella-zoster virus
\end{abstract}

Opportunistic viral infections make an important threat to renal transplant recipients (RTRs), and with the use of more intense newly-developed immunosuppressive drugs; the risk of renal allograft loss due to reactivation of these viruses considerably increased. At the top priority of these viruses, human cytomegalovirus and other herpes viruses in addition to polyomavirus, reactivation of these viruses in these chronically immunosuppressed RTRs can lead to renal impairment and subsequently loss, unless early detected and properly treated.

Citation Al-Obaidi AB, Jasim MB, Hussein MR, Kadhim HS, Habib MA. Opportunistic viral infections after kidney transplantation: A review. Iraqi JMS. 2020; 18(2): 79-93. doi: 10.22578/IJMS.18.2.1

\section{Introduction}

Renal transplantation is the treatment of choice for patients with advanced kidney disease, even when compared with more sophisticated dialysis modalities ${ }^{(1,2)}$. Despite the significant advances in renal transplantation protocols, opportunistic infections especially viruses are still a potential cause of allograft failure, but also have been considered as an important cause of morbidity and mortality after kidney transplantation ${ }^{(3,4)}$. There are many different consequences of viral infections, which might include either direct effect on the graft and hematological dissemination to many other organs, or indirect effects on the patient and the graft ${ }^{(5)}$.
Therefore, prevention, early detection, and prompt treatment of such infections are crucial in kidney transplant recipients ${ }^{(4)}$.

Among all infectious complications, viruses are considered the most common agents because of their abundance, infectivity, and latency ability ${ }^{(4)}$. Herpes viruses like varicella-zoster virus (VZV), Epstein-Barr virus (EBV), and cytomegalovirus (CMV), hepatitis B virus, BK polyomavirus (BKV), and adenovirus are wellknown etiologic agents of viral infections in kidney transplant patients worldwide because of their wide range of distribution ${ }^{(4)}$.

As DNA viruses, they are able to reactivate after affected patients receive immunosuppressive agents. These DNA viruses can cause systemic diseases or allograft dysfunction, especially in the first six months after transplantation ${ }^{(4)}$. CMV and BKV are the most common causes of viral infection after 
kidney transplantation. However, clinical presentations vary ${ }^{(4)}$.

\section{1- Cytomegalovirus (CMV)}

$\mathrm{CMV}$ is a member of herpesviridae family virus, it is a $\beta$-Herpesvirus. It is the largest human herpesvirus, with a 150 to $200 \mathrm{~nm}$ diameter, and it has a lipoproteins envelope and 33 structural proteins, and the core, with a double-stranded DNA $(64 \mathrm{~nm})^{(6,7)}$.

Generally, first infections usually occur in children, and the seroprevalence reaches more than $90 \%$ in the adults' population ${ }^{(8,9)}$. After first infection, the virus might be identified in the CD34+ myeloid progenitors and CD14+ monocytes, in addition to megakaryocytes, and dendritic cells ${ }^{(10,11)}$.

During the situations of immune-suppression, like in solid organ transplants (SOT); CMV reactivation could take place, causing a wide spectrum of clinical manifestations in organ transplanted patients. Studies showed that CMV infection or reactivation is one of the primary infectious problems among renal transplantation, and it causes high incidence of both morbidity and mortality. Human CMV is regarded the most common viral infection in SOT, it is associated with clinically infectious diseases (e.g., fever, pneumonia, gastrointestinal ulcers, hepatitis, and retinitis) with acute or chronic renal allograft dysfunction. About $20-60 \%$ of all renal transplantation recipients (RTR) develop symptomatic CMV infection $(10,12,13)$.

CMV infection could affect the kidney allograft either directly or indirectly. Direct effects of CMV might be CMV syndrome (e.g., fever, myalgia, fatigue, and leucopenia) or could be in the form of tissue invasive diseases (pneumonitis, duodenitis, gastritis, and colitis). While the indirect effects include acute or chronic renal allograft injuries, or allograft rejection, and causing other opportunistic infections mainly fungal (14).

Risk factors for the $\mathrm{CMV}$ reactivation are mainly low lymphocyte count (15,16), low complement activity or natural killer (NK) cells count $(17,18)$, hypo-gammaglobulinemia mainly IgG type ${ }^{(17,19,20)}$, seropositive donor and using lymphocyte depleting drugs $(21,22)$. The rate of occurrence of human $\mathrm{CMV}$ reactivation depends mainly on the donor/recipient serological (IgG) profile and it could reach up to $60 \%$ in RTR patients with D+/R- IgG CMV ${ }^{(23,24)}$. Also, the incidence could increase to $50 \%$ in RTR patient who receive $T$ cell reduction therapy. Prevention of CMV infection after SOTs are prophylaxis anti-viral drugs $(12,21,25)$.

Renal transplants with D+/R- CMV serostatus receive antiviral prophylaxis for more than 200 days (26). The mainstay of treating tissueinvasive CMV diseases and CMV syndrome are intravenous ganciclovir or valganciclovir; these two drugs had the same efficacy on CMVdisease and also a similar long-term outcome (27).

\section{2- Epstein- Barr virus (EBV)}

Human EBV is a gamma-herpesvirus, reported with a sero-prevalence ranging from $70 \%$ to $90 \%$ in healthy subjects over the world (28-31). Clinically, EBV infection presented among RTR in variable manifestations ranging from subclinical to uncomplicated infectious mononucleosis, pneumonitis, hepatitis, generalized lymphadenopathy, hepatosplenomegaly, central nervous system (CNS) disease, gastrointestinal (GIT) disease, and most importantly post-transplant lymphoproliferative disorder (PTLD) ${ }^{(32,33)}$.

The prevalence of PTLD depends on the type of transplanted organ, however, RTR has the lowest. The risk factors for PTLD included type of the transplanted organ, EBV sero-mismatch, and the induction immune-suppressive therapy that is used mainly anti-thymocyte globulin (ATG), belatacept, and muromonab-CD3. The guidelines recommend screening for EBV DNA in blood in high-risk recipients for 1 year after transplantation because of the highest risk of reactivation within the first year (32-35).

Development of PTLD occurs in a biphasic onset, that means most of the EBV-positive RTRs develop PTLD in the first post-transplant 
year, while EBV-negative RTRs develop PTLD 515 years post-transplant (36-38).

Intra-graft PTLD develops in the first 2 years post-transplant, while cerebral-PTLD develops between the $2^{\text {nd }}$ and $7^{\text {th }}$ year posttransplantation. However, the rate of GIT-PTLD is very low in the $1^{\text {st }} 5$ years and then increase in the 6th and 7th year post-transplantation (39).

Some of studies show that EBV DNAmia was detected in 19/57 (33\%) of RTRs. About 50 and $51.7 \%$ of RTRs included in this study had either acute or chronic allograft impairment. In that study, RTRs with positive EBV DNAmia were commonly with high risk of having both acute and chronic renal impairment $(P=0.0001)$, in addition, high serum creatinine levels in RTRs showed a significant risk to have EBV infection ${ }^{(40)}$. A study was conducted in Germany showed that EBV infection is an underestimated cause of renal allograft impairment and could be rejection of the renal allograft ${ }^{(41)}$.

However, the exact risk cause for EBV infection to cause renal impairment is not well understood. Several explanations were speculated, EBV-induced cytotoxic T lymphocyte contains clones that are reactive to self-MHC-peptide which have strong allo-crossreactivity against allo-MHC-peptides (8,42-44).

Other explanation is that EBV could counteract the immune-suppression of $T$ lymphocytes in which induction of $\mathrm{T}$ cell immune response by EBV could be a limiting-step for immunesuppressive effects of drugs that were taken after renal transplantation (45).

In addition, the other EBV replicates in Blymphocytes; which results in induction of $B$ cells'-signaling pathway of producing immunoglobulins, which might result in an increased formation of heterophil antibodies. These heterophil antibodies could be another co-factor for tissues-targeting in the transplanted kidney, also complement activation might lead to renal glomeruli destruction (46).

\section{3- Polyomaviruses}

\subsection{BK Polyomavirus (BKV)}

BKV is a non- enveloped, ds DNA virus it is a member of Polyomaviridae family. It was first identified in 1971 in a RTR-patient who developed renal allograft impairment following kidney transplantation (47). BKV infection after renal transplantation could cause BKVassociated nephropathy (BKVN), and graftfailure, hemorrhagic cystitis, ureteric stricture, and tubule-interstitial nephritis ${ }^{(48)}$.

After the primary infection, BKV becomes latent in the uro-thelium and renal-tubular cells. After starting immune-suppression, the virus reactivates and starts replication, leading to BKV-viremia and finally affects the kidney allograft, causing BKVN. Rate of occurrence of $B K V N$ is variable range from $1-10 \%{ }^{(49-52)}$.

Generally, there is a high seroprevalence rate of BK polyomavirus among healthy individuals, which reaches up to $91 \%{ }^{(53)}$. A study of 400 blood donors, sero-prevalence rate reduced from $87 \%$ in young age-group (20 to 29 years) to $71 \%$ in the older age-group (50 to 59 years). BKV-shedding in urine was up to $7 \%$ in healthy subjects, however, BK-viremia was not found in blood of those subjects (54). A study on 51 healthy subjects found BKV-shedding in urine was in about $16 \%$ of subjects, 28 of these healthy subjects were followed up for 6 months and the virus shedding in urine was very low in the majority of them ${ }^{(55)}$. Another study on 150 blood donors found that seroprevalence of BKV was $82 \%{ }^{(56)}$.

Risk factors for the development of BKV infections in the renal transplant recipients could be classified into donor, recipient and transplantation related risk factors ${ }^{(47)}$. Studies showed that BKV viremia and BKVN occur most commonly in the $1^{\text {st }}$ post-transplantation year, when immune-suppression is the most intense (57-59).

A study showed that the shedding of BKV in urine is significantly associated with BK viremia, BKVN, and allograft loss, RTRs who had positive urinary decoy cells were found to have BKV shedding in $56.3 \%$ of patients by urinary 
polymerase chain reaction (PCR) testing. Also, $B K$ viremia was positive in $93 \%$, and BKVN was diagnosed by histopathological study in $48 \%$ of those patients. Most importantly, BK viremia higher than 104 copies $/ \mathrm{ml}$ which is highly significantly-associated with a biopsy- proven BKVN $(P<0.0001)^{(60)}$.

BK polyomavirus infection presented with a gradual increase in serum creatinine levels with a tubule-interstitial nephritis that is mimicking rejection, which makes a therapeutic dilemma. The reduction of immune-suppression, which is needed to manage BKV infection is the opposite to the increase in immunesuppressive drugs which were needed to avoid rejection (51).

Schold et al. ${ }^{(61)}$, investigated the incidence and risk factors for BK polyomavirus infection in RTRs. The significant and independent-risk factors were: a young age, donors over 65 years age, a male recipient, a female donor, higher HLA-mismatched, tacrolimus immunesuppression regimen, and induction by thymoglobulin.

In one study conducted on 99 RTR the results showed that BK viremia was in 12 out of 99 RTR (12.12\%) with a viral load (VL) ranging from $1 \times 10^{2}$ to $1 \times 10^{9}$ copies/ml ${ }^{(62)}$. In a study the results revealed there was a significant correlation between creatinine values and BKV viral load ( $r=+0.576)(p=0.05)^{(62)}$.

There is no significant association between the type of immune-suppressive regimen and BKV viremia $(p=0.42)$. Many of studies found a highly significant correlation between decoy cells in the Pap-stained urine cytology smears and BK viremia one of these of studies conducted by Al-Obaidi et al., $\mathrm{P}$ value were $(p=0.001)^{(63)}$. Reactivation of BKV could cause hemorrhagic cystitis, ureteric stenosis and bacterial super-infections ${ }^{(57-59)}$. Some of these studies found BK infection highly associated with co-infection of CMV, whereas other studied showed no significant association between these two viruses in RTRs $(59,64-66)$.

Differences in the type of cellular immune response to BKV might play important role in the reduction of $B K V$ replication. Positive $B K$ viremia patients had lower CD4 count; and higher CD8 in the pre-transplant samples, as compared to the transplanted subjects who didn't develop BK viremia (67).

\subsection{JC Polyomavirus (JCV)}

JCV is member of the Polyomaviridae family, it is a non-enveloped virus with a doublestranded DNA genome (68). JCV was first identified by Padgett et al. ${ }^{(69)}$ in 1971 in brain of patient with the initials JC, who died because of progressive multifocal leuko-encephalopathy (PML), a progressive deadly demyelinating disease in the CNS.

Studies of JCV in kidney transplanted recipients were published after identifying the virus $(70,71)$. Infection by JCV was observed in RTRs as nephropathy or PML. Progressive Multifocal leuko-encephalopathy rarely occurs in kidney transplanted patients and it is mainly correlated with high levels of JC viral DNA in the cerebrospinal fluid (CSF) (72).

Kidney transplanted recipients had the highest risk of complication with polyomavirus nephropathy (PVAN) as compared to other SOT due to the development of allograft injury due to drug toxicity, cold ischemia, and HLAmismatch, all these in addition to polyomaviruses activation $(73,74)$. Polyomavirus nephropathy with renal allograft dysfunction and loss has been significantly increasing since 1990s; so that, a pathological role of JCV should be considered ${ }^{(75,76)}$.

Gardner et al. (77) performed prospective, serological study on JCV infection in 48 kidney transplant recipients, and showed that $54 \%$ of the subjects were sero-positive before transplantation, and in $23 \%$ of the seronegative patients, JCV infection occurred in the first 3 months post-transplantation. Most surveys that measured JCV viremia in patients' samples, had reported wide range of JCV loads, from $2.0 \times 10^{3}$ to $1 \times 10^{7}$ copies $/ \mathrm{ml}^{(40,78-83)}$. Most of studies showed that JC viral load was significantly increased in the RTRs compared to the healthy group, verifying the correlation 
between patients' immune status and viral loads ${ }^{(84,85)}$.

According to a study conducted on 71 RTRs Quantitative real time PCR gave positive JCV viruria in 31 out of $71(43.7 \%)$ RTRs and $2(10 \%)$ out of the 20 controls, $(P=0.007){ }^{(84)}$. However, JC viremia in the RTRs seems to be very rare, and low as it is shown in some studies. The extent of tissue involvement by JCV is less than that in BKV nephropathy. However, some of studies suggested a role of JCV in renal allograft nephropathy among RTRs just like BKV $(60,67,86-89)$.

Most of studies, documented a significant correlation between JCV and abnormal creatinine clearance, in one of these this study where a about $58 \%$ of those who had abnormal creatinine clearance also had positive JC viruria, which was significantly higher than those who had negative JC viruria. Most of studies found that the Decoy cell shedding was not significantly associated with JC viruria, unlike BKV which most of studies showed significant correlation with DC shedding. There are studies, showed that cyclosporine (CYC) is a risk factor for JCV reactivation. In once found 21RTRs out of 31 RTRs (67.7\%) positive JC viruria were on CYC regimen ${ }^{(67,90-95)}$.

\section{4- Human herpesviruses- $6,-7$ and -8}

Human herpesvirus- 6 and -7 (HHV-6 and HHV7) are well recognized pathogens in organ transplant recipients, they are homologous to $\mathrm{CMV}$ and in the same subfamily. Human herpesvirus- 6 in RTR has been found to be associated with fever, rash, encephalitis, hepatitis, myelo-suppression, and interstitial pneumonitis ${ }^{(11,96)}$. The virus was first isolated from the lymphocytes of immune-

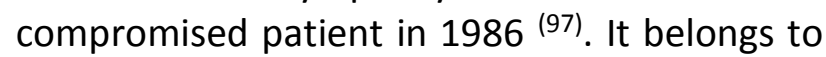
the beta-herpes subfamily, and it is closely related to CMV and HHV-7, all of these beta herpesviruses are widely distributed in human populations. Human herpesvirus- 6 and -7 are also called the Roseola viruses and are the causal agents of roseola infantum (also known as Exantema subitum), a febrile illness that is characterized by fever and skin rash during early childhood ${ }^{(98)}$.

\subsection{Human herpesvirus-6 (HHV-6)}

HHV- 6 is a large DNA virus $200 \mathrm{~nm}$ in diameter, with a linear double-stranded DNA genome (99). Clinically, HHV-6 infections are mostly mild or subclinical, however, complications like seizures, respiratory, otitis, or GIT complications, and rarely hepatitis and encephalitis have been reported $(100,101)$. HHV- 6 is infections mostly occur before 2 years of age, saliva is the most likely mode of transmission. Like other herpesviruses; HHV-6 persists in the host in a latent form; and its sero-prevalence in the adult populations is up to $95 \%{ }^{(102,103)}$. Though the precise site of latency of the virus in the body is not well known, the salivary glands and bronchi represent the most likely sites of latency, in addition, neurons, and glial cells were also found to be sites of HHV-6 latency ${ }^{(104)}$. HHV-6 is infection was frequently reactivated in immune-suppressed renal transplant patients (105). The virus could be transmitted through renal transplantation; however, infection mainly results from reactivation of the recipient's endogenous (latent virus), due to the high sero-prevalence rate of the virus in the general population $(102,103)$.

HHV- 6 was found to be a cause of infection in renal transplant recipients (106-108). However, most infections are asymptomatic after renal transplantation (109,110). In addition, viral DNA was frequently detected in peripheral blood mononuclear cells in asymptomatic renal transplant patients ${ }^{(111)}$. However, detection of HHV-6-specific antigens by immunehistochemistry in kidney biopsy were found to be associated with renal pathological conditions, like acute or chronic allograft rejection or nephropathy $\left({ }^{107,112)}\right.$.

Reactivation of HHV-6 usually occur in the first month following transplantation and though HHV-6 infections in renal transplant recipients are usually mild, however, symptomatic and 
even fatal HHV-6 infections have been reported ${ }^{(113)}$.

There are several diagnostic methods; most importantly; quantification of viral DNA by PCR in blood, plasma or serum samples, however, there is no well-established HHV-6 VL thresholds used to recognize the levels of virus replication and establishing symptomatic infection (114-116).

In one study HHV-6 infection was observed in 8 of 49 (16.3\%) RTRs (increasing VL over three months); their mean PTP was $6.4 \pm 3.5$ months, $75 \%$ ( 6 out of these 8 patients) had biopsyproven renal allograft rejection $(P<0.001)$, and all of them $(100 \%)$ were symptomatic $(p=0.002)$, with $50 \%$ had fever, $25 \%$ had skin rash, and another 2 of 8 (25\%) patients had upper respiratory tract infection. Viral loads (VL) were high (median viral load $4.5 \times 10^{4}$ copies/mL blood), $(p<0.001)$ (117). In other studies, HHV- 6 infection has been detected in $38-55 \%$ of kidney transplant recipients $(107,118)$.

\subsection{Human herpesvirus-7 (HHV-7)}

Member of the beta herpesvirus subgroup was first isolated in 1990 in the blood of a healthy subject ${ }^{(119)}$. It is a ubiquitous virus with the primary infections occur early during childhood, and thus $>90 \%$ are sero-positive (120). HHV-7 establishes latent infections in the monocytes ${ }^{(121)}$. It reactivates following organ transplantation (122-124); HHV-7 was found to be associated with graft rejection or impaired renal function, bone marrow suppression, and higher risk CMV disease (125-127).

Patients had CMV disease are at increased risk to have HHV-7 DNA than those who had asymptomatic CMV infection (31\% versus $0 \%$, $\mathrm{P}=0.13){ }^{(128)}$. In a study in kidney transplant recipients, patients with CMV and HHV-7 coinfection were at increased risk to develop CMV disease than those who had CMV infection only ${ }^{(129)}$.

A recent study conducted by our team, investigated CMV, HHV-6 and HHV-7 infections together in kidney transplanted patients and found that co-infections increased the risk of nephropathy and allograft rejection. Also, roseola viruses increase the frequency and pathological effect of CMV infection in RTR (unpublished data).

\subsection{Human Herpes Virus-8 (HHV-8)}

HHV-8 or called Kaposi's sarcoma-associated herpes virus (KSHV) is the causal agent of all forms of Kaposi's sarcomas (KS), including posttransplant KS. HHV-8 is a gamma-herpesvirus of the genus Rhadinovirus, which are group of transforming viruses and have the ability to cause tumors in their hosts ${ }^{(130)}$. KSHV can be found in SOT recipients in a prevalence of 0.5 to $5 \%$, which depends on the geographical origin, the rate of occurrence is 1,000-fold more common in SOT than in the healthy subjects ${ }^{(131)}$.

Occurrence of KS among SOT is mainly associated with the use of immuno-suppressive therapy (especially calcineurin inhibitors), as evidenced by the remission of KS lesions following the reduction or withdrawal of the immunosuppressive therapy (132-135). Several studies noted the reactivation of HHV- 8 in the transplanted recipients $(136,137)$. HHV-8 was found to reactivate among SOT who were seropositive before transplantation and high number of sero-negative subjects, including children, were found to sero-convert to HHV-8 after transplantation (138).

In renal transplantation, the duration of immunosuppression and its intensity, and HHV8 sero-positivity pre-transplantation all increased the risk of KS occurrence, which usually starts 13 months post-transplantation (139).

A study conducted on a 70-year-old kidney transplanted woman who was suffering from purplish, macular rash on her lower limbs without any pain or pruritus. On examination there was large cutaneous purplish infiltrative plaques on the lower limbs highly suggestive of KS ${ }^{(140)}$. 


\section{5- Varicella-zoster virus (VZV)}

VZV is a ds-DNA virus and a member of herpesvirus family, and has the ability for life-long latency in the cranial nerves or dorsal nerveroot ganglia and persists in the subjects for life after primary infection, and it could be the second most common viral infection in SOT recipients (after CMV), reaches up to $29 \%$. VZV occurs in about $11 \%$ of SOT recipients within the first 4 years of transplantation due to the long-term immune-suppressive therapy (141-144). The incidence of VZV was increased among SOT receipts used Mycophenolate Mofoetil. VZV commonly occurs in the first 6 months posttransplantation; however, it can manifest longer after transplant. VZV infection in RTRs mainly results from reactivation rather than a primary infection, and severe sequel occurs $(145,146)$.

VZV infection causes two clinical different disease forms, vesicular lesions on the trunk, head and extremities, characterize primary disease (varicella or chickenpox), the second form is herpes zoster (shingles) which is characterized by very painful unilateral vesicular eruption, which rarely might disseminate ${ }^{(147)}$.

VZV or shingles occurs with an incidence of 1.53.0 cases $/ 1000$ in the general population annually and it is mainly related to age with incidence rising to 10 cases $/ 1000$ in subjects over 65 years of age. Incidence of VZV in SOT recipient increases 10-100 times, reaching up to $1-12 \%{ }^{(148,149)}$.

In one study included 240 patients, VZV prevalence was $3.33 \%$, which is a lower prevalence as compared to other studies that had reported a high prevalence (150). These findings showed that VZV infection was higher in males, however, another study showed that VZV was higher in females (151). All of the patients who developed zoster infection had a previous history of VZV infection before kidney transplantation. The risk rate and severity of zoster infection is mainly related to the degree of the immune-suppression $(147,152,153)$.
In other study, the prevalence rate of VZV in kidney transplants was $3.51 \%$. However, female gender was considered as a risk factor for developing zoster infection. Majority of patients in this study had zoster infection in the first post-transplantation year. Only 4 patients developed VZV lately after transplantation, so that the median time of onset was 2.13 years. However, other previous studies showed that the onset of VZV infection after SOT could be between 2 and 92 months $(141,143,154,155)$.

\section{6- Adenovirus (ADV)}

ADV belongs to the Adenoviridae family, in the past; ADV have made continuous challenges and wide range of clinical manifestations. ADVs are classified into 7 species, from A to $G(156,157)$. More than 71 types were reported according to the gene bank of human ADV genotype classification ${ }^{(158)}$.

First isolated from the adenoids over 60 years ago, and these human ADVs were known to cause a wide spectrum of diseases, including gastroenteritis, kerato-conjunctivitis, upper and lower respiratory tract infections, hemorrhagic cystitis, and it produce in vitro cytolysis in these tissues ${ }^{(159)}$.

ADV is the causative agent of around $5-10 \%$ of childhood febrile diseases. In an immunocompetent host, ADV infection occurs as mild, and self-limited upper respiratory tract infections. Most people have positive serologic evidence of previous adenovirus infections by the age of 10 years ${ }^{(160)}$. After the primary infection, adenovirus develops life-long latent infection in the lymphoepithelial tissues (159).

In the immuno-compromised hosts, adenovirus infections are among a spectrum ranging from asymptomatic viral shedding to a fataldisseminated disease ${ }^{(159)}$. In the SOT, usually the primary site of ADV infection is related to the type of transplanted organ. Some of the signs and symptoms occur in the lung, liver, kidney, and small bowel transplantations, which included pneumonia, nephritis, hepatitis, enteritis, hemorrhagic cystitis, and rarely fataldisseminated disease ${ }^{(161)}$. 
In RTRs, most common clinical manifestation is acute hemorrhagic cystitis and, less commonly pneumonia, with about $17 \%$ fatality rate ${ }^{(162)}$. ADV infections occur as either primary infection or reactivation of a previous infection, and presents as pneumonitis, nephritis, hemorrhagic cystitis or colitis and diarrhea in less than $2 \%$ of ADV cases, also the infection might become systemic and cause multi-organ failure (163-165).

In RTR adenovirus infections usually were shown very early after transplantation, and presented with very low absolute lymphocyte counts, and these patients might develop more severe complications and disseminated disease, for this reason lymphocyte counts could be used as a predictor for adenovirus disease and patient's outcome ${ }^{(166)}$. In addition, ADV infection in renal transplantation can be suspected when there are decoy cells (DC) in Pap-stained urine cytology however, significantly less common than polyomaviruses $(167,168)$.

A study conducted on 71 RTRs Revealed that ADV viremia has been detected in the plasma samples of $21 \%$ of the RTRs (15 out of 71$)^{(169)}$. Other studies showed that ADV infection can range from 5 to $22 \%(170,171)$.

Other study was case report study on 68-yearold man had renal transplantation, developed fever to $40{ }^{\circ} \mathrm{C}$ and rigors, macroscopic hematuria, diarrhea, respiratory symptoms, and conjunctivitis. This was followed by deterioration of the graft function. Testing of the CSF by PCR was negative for CMV, EBV and HSV, then urine sample collected near the onset of macroscopic hematuria returned PCR positive for adenovirus. Subsequent blood PCR testing was also positive (172).

\section{References}

1. Rabbat CG, Thorpe KE, Russell JD, et al. Comparison of mortality risk for dialysis patients and cadaveric first renal transplant recipients in Ontario, Canada. J Am Soc Nephrol. 2000; 11(5): 917-22.

2. Molnar MZ, Ravel V, Streja $E$, et al. Racial differences in survival of incident home hemodialysis and kidney transplant patients.
Transplantation. 2016; 100(10): 2203-10. doi: 10.1097/TP.0000000000001005.

3. Unal E, Topcu A, Demirpolat MT, et al. Viral infections after kidney transplantation: An updated review. Int J Virol AIDS. 2018; 5(1): 40-3.

4. Vanichanan J, Udomkarnjananun $S$, Avihingsanon $Y$, et al. Common viral infections in kidney transplant recipients. Kidney Res Clin Pract. 2018; 37(4): 32337. doi: 10.23876/j.krcp.18.0063.

5. Weikert BC, Blumberg EA. Viral infection after renal transplantation: surveillance and management. Clin J Am Soc Nephrol. 2008; 3 Suppl 2(Suppl 2): S76-86. doi: 10.2215/CJN.02900707.

6. Pass RF. Epidemiology and transmission of cytomegalovirus. J Infect Dis. 1985; 152(2): 243-8. doi: 10.1093/infdis/152.2.243.

7. Humar A, Snydman D, AST Infectious Diseases Community of Practice. Cytomegalovirus in solid organ transplant recipients. Am J Transplant. 2009; 9 Suppl 4: S78-86. doi: 10.1111/j.16006143.2009.02897.x.

8. Kasiske BL, Zeier MG, Chapman JR, et al. KDIGO clinical practice guideline for the care of kidney transplant recipients: a summary. Kidney Int. 2010; 77(4): 299-311. doi: 10.1038/ki.2009.377. Epub 2009 Oct 21.

9. Kuo HT, Ye X, Sampaio MS, et al. Cytomegalovirus serostatus pairing and deceased donor kidney transplant outcomes in adult recipients with antiviral prophylaxis. Transplantation. 2010; 90(10): 1091-8. doi: 10.1097/TP.0b013e3181f7c053.

10. Paya CV. Prevention of cytomegalovirus disease in recipients of solid-organ transplants. Clin Infect Dis. 2001; 32(4): 596-603. doi: 10.1086/318724.

11. Kotton CN, Fishman JA. Viral infection in the renal transplant recipient. J Am Soc Nephrol. 2005; 16(6): 1758-74. doi: 10.1681/ASN.2004121113.

12. Brennan DC. Cytomegalovirus in renal transplantation. J Am Soc Nephrol. 2001; 12(4): 848-55.

13. Cordero E, Casasola C, Ecarma R, et al. Cytomegalovirus disease in kidney transplant recipients: incidence, clinical profile, and risk factors. Transplant Proc. 2012; 44(3): 694-700. doi: 10.1016/j.transproceed.2011.11.053.

14. Razonable RR, Humar A, AST Infectious Diseases Community of Practice. Cytomegalovirus in solid organ transplantation. Am J Transplant. 2013; 13 Suppl 4: 93-106. doi: 10.1111/ajt.12103.

15. Natori $Y$, Humar $A$, Husain $S$, et al. Recurrence of CMV infection and the effect of prolonged antivirals in organ transplant recipients. Transplantation. 2017; 101(6): 1449-54. doi: 10.1097/TP.0000000000001338.

16. Nierenberg NE, Poutsiaka DD, Chow JK, et al. Pretransplant lymphopenia is a novel prognostic factor in cytomegalovirus and noncytomegalovirus 
invasive infections after liver transplantation. Liver Transpl. 2014; 20(12): 1497-507. doi: 10.1002/lt.23991.

17. Sarmiento $E$, Jaramillo $M$, Calahorra $L$, et al. Evaluation of humoral immunity profiles to identify heart recipients at risk for development of severe infections: A multicenter prospective study. J Heart Lung Transplant. 2017; 36(5): 529-39. doi: 10.1016/j.healun.2016.10.004.

18. Sarmiento E, del Pozo N, Gallego A, et al. Decreased levels of serum complement C3 and natural killer cells add to the predictive value of total immunoglobulin $G$ for severe infection in heart transplant recipients. Transpl Infect Dis. 2012; 14(5): 526-39. doi: 10.1111/j.13993062.2012.00757.x.

19. Sarmiento E, Navarro J, Fernandez-Yañez J, et al. Evaluation of an immunological score to assess the risk of severe infection in heart recipients. Transpl Infect Dis. 2014; 16(5): 802-12. doi: 10.1111/tid.12284.

20. Goldfarb NS, Avery RK, Goormastic $M$, et al. Hypogammaglobulinemia in lung transplant recipients. Transplantation. 2001; 71(2): 242-6. doi: 10.1097/00007890-200101270-00013.

21. Chiasakul T, Townamchai $\mathrm{N}$, Jutivorakool $\mathrm{K}$, et al. Risk factors of cytomegalovirus disease in kidney transplant recipients: a single-center study in Thailand. Transplant Proc. 2015; 47(8): 2460-4. doi: 10.1016/j.transproceed.2015.08.011.

22. Kotton CN, Kumar D, Caliendo AM, et al. The Third International Consensus Guidelines on the management of cytomegalovirus in solid-organ transplantation. Transplantation. 2018; 102(6): 900-931. doi: 10.1097/TP.0000000000002191.

23. Hartmann A, Sagedal S, Hjelmesaeth J. The natural course of cytomegalovirus infection and disease in renal transplant recipients. Transplantation. 2006; 82(2 Suppl): S15-7. doi: 10.1097/01.tp.0000230460.42558.b0.

24. De Keyzer K, Van Laecke $S$, Peeters $P$, et al. Human cytomegalovirus and kidney transplantation: a clinician's update. Am J Kidney Dis. 2011; 58(1): 118-26. doi: 10.1053/j.ajkd.2011.04.010.

25. López-Oliva MO, Flores J, Madero $\mathrm{R}$, et al. Cytomegalovirus infection after kidney transplantation and long-term graft loss. Nefrologia. 2017; 37(5): 515-25. English, Spanish. doi: 10.1016/j.nefro.2016.11.018.

26. Humar A, Lebranchu Y, Vincenti F, et al. The efficacy and safety of 200 days valganciclovir cytomegalovirus prophylaxis in high-risk kidney transplant recipients. Am J Transplant. 2010; 10(5): 1228-37. doi: 10.1111/j.1600-6143.2010.03074.x.

27. Åsberg $A$, Humar $A$, Rollag $H$, et al. Lessons learned from a randomized study of oral valganciclovir versus parenteral ganciclovir treatment of cytomegalovirus disease in solid organ transplant recipients: The VICTOR trial. Clin Infect Dis. 2016; 62(9): 1154-60. doi: 10.1093/cid/ciw084.

28. Redha AQ, Al-Obaidi AB, Kadhim HS, et al. Seroprevalence and plasma viral load of Epstein Barr Virus among Iraqi blood donors. Iraqi J Med Sci. 2017; 15(2): 135-42.

29. Chen $\mathrm{CY}$, Huang $\mathrm{KY}$, Shen JH, et al. A large-scale seroprevalence of Epstein-Barr virus in Taiwan. PLoS One. 2015; 10(1): e0115836. doi: 10.1371/journal.pone.0115836.

30. Balfour HH Jr, Odumade OA, Schmeling DO, et al. Behavioral, virologic, and immunologic factors associated with acquisition and severity of primary Epstein-Barr virus infection in university students. J Infect Dis. 2013; 207(1): 80-8. doi: 10.1093/infdis/jis646.

31. Elansary M, El-Haddad HE, Sharaf Eldin UAA, et al. Seroprevalence and real-time PCR study of EpsteinBarr virus and the value of screening in pretransplant patients. Egypt J Intern Med. 2016; 28: 9-15.

32. Dierickx D, Habermann TM. Post-Transplantation Lymphoproliferative Disorders in Adults. N Engl J Med. 2018; 378(6): 549-562. doi: 10.1056/NEJMra1702693.

33. Opelz G, Döhler B, Ruhenstroth A. Cytomegalovirus prophylaxis and graft outcome in solid organ transplantation: a collaborative transplant study report. Am J Transplant. 2004; 4(6): 928-36. doi: 10.1111/j.1600-6143.2004.00451.x.

34. Green M, Michaels MG. Epstein-Barr virus infection and posttransplant lymphoproliferative disorder. Am J Transplant. 2013; 13 Suppl 3: 41-54; quiz 54. doi: 10.1111/ajt.12004.

35. Parker A, Bowles K, Bradley JA, et al. Diagnosis of post-transplant lymphoproliferative disorder in solid organ transplant recipients - BCSH and BTS Guidelines. Br J Haematol. 2010; 149(5): 675-92. doi: 10.1111/j.1365-2141.2010.08161.x.

36. Dierickx D, Tousseyn T, Sagaert $X$, et al. Singlecenter analysis of biopsy-confirmed posttransplant lymphoproliferative disorder: incidence, clinicopathological characteristics and prognostic factors. Leuk Lymphoma. 2013; 54(11): 2433-40. doi: 10.3109/10428194.2013.780655.

37. Morton $M$, Coupes $B$, Roberts SA, et al. Epstein-Barr virus infection in adult renal transplant recipients. Am J Transplant. 2014; 14(7): 1619-29. doi: 10.1111/ajt.12703.

38. Quinlan SC, Pfeiffer RM, Morton LM, et al. Risk factors for early-onset and late-onset posttransplant lymphoproliferative disorder in kidney recipients in the United States. Am J Hematol. 2011; 86(2): 206-9. doi: 10.1002/ajh.21911.

39. Caillard S, Lamy FX, Quelen C, et al. Epidemiology of posttransplant lymphoproliferative disorders in 
adult kidney and kidney pancreas recipients: report of the French registry and analysis of subgroups of lymphomas. Am J Transplant. 2012; 12(3): 682-93. doi: 10.1111/j.1600-6143.2011.03896.x.

40. Shams-aldein $S A$, Abdlameer AS, Al-Obaidi AB, et al. Detection of Epstein Barr Virus in renal transplant recipients: two centers study. Iraqi J Med Sci. 2015; 13(2): 191-9.

41. Hornef MW, Bein G, Fricke L, et al. Coincidence of Epstein-Barr virus reactivation, cytomegalovirus infection, and rejection episodes in renal transplant recipients. Transplantation. 1995; 60(5): 474-80. doi: 10.1097/00007890-199509000-00013.

42. Allen UD, Farkas $G$, Hébert $D$, et al. Risk factors for post-transplant lymphoproliferative disorder in pediatric patients: a case-control study. Pediatr Transplant. 2005; 9(4): 450-5. doi: 10.1111/j.13993046.2005.00318.x.

43. Burrows SR, Khanna R, Burrows JM, et al. An alloresponse in humans is dominated by cytotoxic $T$ lymphocytes (CTL) cross-reactive with a single Epstein-Barr virus CTL epitope: implications for graft-versus-host disease. J Exp Med. 1994; 179(4): 1155-61. doi: 10.1084/jem.179.4.1155.

44. Burrows SR, Khanna R, Silins SL, et al. The influence of antiviral T-cell responses on the alloreactive repertoire. Immunol Today. 1999; 20(5): 203-7. doi: 10.1016/s0167-5699(98)01429-7.

45. Bamoulid J, Courivaud C, Coaquette A, et al. Subclinical Epstein-Barr virus viremia among adult renal transplant recipients: incidence and consequences. Am J Transplant. 2013; 13(3): 65662. doi: 10.1111/ajt.12009.

46. Shannon-Lowe CD, Neuhierl B, Baldwin G, et al. Resting $B$ cells as a transfer vehicle for Epstein-Barr virus infection of epithelial cells. Proc Natl Acad Sci U S A. 2006; 103(18): 7065-70. doi: 10.1073/pnas.0510512103.

47. Muhsin SA, Wojciechowski D. BK virus in transplant recipients: current perspectives. Transplant Res Risk Manag. 2019; 11: 47-58. doi: 10.2147/TRRM.S188021.

48. Hirsch HH, Randhawa $P$, AST Infectious Diseases Community of Practice. BK polyomavirus in solid organ transplantation. Am J Transplant. 2013 Mar; 13 Suppl 4: 179-88. doi: 10.1111/ajt.12110.

49. Kalble T, Alcaraz K, Budde K, et al. Guidelines on renal transplantation. Arnhem: European Association of Urology; 2009.

50. Tremolada S, Akan S, Otte J, et al. Rare subtypes of BK virus are viable and frequently detected in renal transplant recipients with BK virus-associated nephropathy. Virology. 2010; 404(2): 312-8. doi: 10.1016/j.virol.2010.05.012.

51. Bohl DL, Brennan DC. BK virus nephropathy and kidney transplantation. Clin J Am Soc Nephrol.
2007; 2 Suppl 1: S36-46. doi: 10.2215/CJN.00920207.

52. Sawinski D, Goral S. BK virus infection: an update on diagnosis and treatment. Nephrol Dial Transplant. 2015; 30(2): 209-17. doi: 10.1093/ndt/gfu023.

53. Knowles WA, Pipkin $P$, Andrews $N$, et al. Population-based study of antibody to the human polyomaviruses BKV and JCV and the simian polyomavirus SV40. J Med Virol. 2003; 71(1): 11523. doi: 10.1002/jmv.10450.

54. Egli A, Infanti L, Dumoulin A, et al. Prevalence of polyomavirus BK and JC infection and replication in 400 healthy blood donors. J Infect Dis. 2009; 199(6): 837-46. doi: 10.1086/597126.

55. Polo C, Pérez JL, Mielnichuck $A$, et al. Prevalence and patterns of polyomavirus urinary excretion in immunocompetent adults and children. Clin Microbiol Infect. 2004; 10(7): 640-4. doi: 10.1111/j.1469-0691.2004.00882.x.

56. Kean JM, Rao S, Wang $M$, et al. Seroepidemiology of human polyomaviruses. PLoS Pathog. 2009; 5(3): e1000363. doi: 10.1371/journal.ppat.1000363.

57. Howell DN, Smith SR, Butterly DW, et al. Diagnosis and management of $B K$ polyomavirus interstitial nephritis in renal transplant recipients. Transplantation. 1999; 68(9): 1279-88. doi: 10.1097/00007890-199911150-00011.

58. Binet I, Nickeleit $\mathrm{V}$, Hirsch $\mathrm{HH}$, et al. Polyomavirus disease under new immunosuppressive drugs: a cause of renal graft dysfunction and graft loss. Transplantation. 1999; 67(6): 918-22. doi: 10.1097/00007890-199903270-00022.

59. Agha I, Brennan DC. BK virus and immunosuppressive agents. Adv Exp Med Biol. 2006; 577: 174-84. doi: 10.1007/0-387-32957-9_12.

60. Drachenberg CB, Hirsch HH, Papadimitriou JC, et al. Polyomavirus $\mathrm{BK}$ versus JC replication and nephropathy in renal transplant recipients: a prospective evaluation. Transplantation. 2007; 84(3): 323-30. doi: 10.1097/01.tp.0000269706.59977.a5.

61. Schold JD, Rehman S, Kayle LK et al. Treatment for BK virus: incidence, risk factors and outcomes for kidney transplant recipients in the United States. Transpl Int. 2009; 22(6): 626-34. doi: 10.1111/j.1432-2277.2009.00842.x.

62. Al-Obaidi $A B, A b d K H, K a d h i m ~ H S$, et al. BK polyomavirus and Cytomegalovirus Co-infections in renal transplant recipients: a single center study. Int J Adv Res. 2015; 3: 856-64.

63. Al-Obaidi AB, Qasim BJ, Husain AG, et al. BK polyomavirus-infected Deco cells in urine cytology specimens of renal transplant recipients. Iraqi J Med Sci. 2015; 13: 70-5.

64. Toyoda M, Puliyanda DP, Amet N, et al. Coinfection of polyomavirus-BK and cytomegalovirus 
in renal transplant recipients. Transplantation. 2005; 80(2): 198-205. doi: 10.1097/01.tp.0000165110.78397.93.

65. Park SB, Kwak JH, Lee KT, et al. Polyoma virusassociated nephropathy and concurrent cytomegalovirus infection in the kidney transplant recipients. Transplant Proc. 2006; 38(7): 2059-61. doi: 10.1016/j.transproceed.2006.06.107.

66. Nasiri S, Ahmadi SF, Lessan-Pezeshki M, et al. Lack of cytomegalovirus and polyomavirus coexistence in Iranian kidney transplant recipients. Transplant Proc. 2011; 43(2): 536-9. doi: 10.1016/j.transproceed.2011.01.057.

67. Al-Obaidi AB, Shamran HA, Hussein AG, et al. The possible role of JC polyomavirus after kidney transplantation. J Global Pharma Technology. 2018, 10(06): 580-7.

68. Imperiale MJ. The human polyomaviruses: an overview. In: Khalili K, Stoner GL (eds). Human polyomaviruses: molecular and clinical perspective. New York, NY, USA: John Wiley \& Sons; 2001. p. 5371.

69. Padgett BL, Walker DL, ZuRhein GM, et al. Cultivation of papova-like virus from human brain with progressive multifocal leucoencephalopathy. Lancet. 1971; 1(7712): 1257-60. doi: 10.1016/s0140-6736(71)91777-6.

70. Gardner SD. Implication of papova viruses in human diseases. In: Kurstakand E, Kurstak C (eds). Comparative diagnosis of viral disease, human and related viruses. New York, NY, USA: Academic Press; 1977. p. 41-4.

71. Hogan TF, Borden EC, McBain JA, et al. Human polyomavirus infections with JC virus and BK virus in renal transplant patients. Ann Intern Med. 1980; 92(3): 373-8. doi: 10.7326/0003-4819-92-3-373.

72. Crowder $C D$, Gyure $K A$, Drachenberg $C B$, et al. Successful outcome of progressive multifocal leukoencephalopathy in a renal transplant patient. Am J Transplant. 2005; 5(5): 1151-8. doi: 10.1111/j.1600-6143.2005.00800.x.

73. Nickeleit $\mathrm{V}$, Hirsch $\mathrm{HH}$, Zeiler $\mathrm{M}$, et al. BK-virus nephropathy in renal transplants-tubular necrosis, MHC-class II expression and rejection in a puzzling game. Nephrol Dial Transplant. 2000; 15(3): 324-32. doi: $10.1093 / \mathrm{ndt} / 15.3 .324$.

74. Bohl DL, Storch GA, Ryschkewitsch C, et al. Donor origin of $B K$ virus in renal transplantation and role of HLA C7 in susceptibility to sustained BK viremia. Am J Transplant. 2005; 5(9): 2213-21. doi: 10.1111/j.1600-6143.2005.01000.x.

75. Hirsch HH, Steiger J. Polyomavirus BK. Lancet Infect Dis. 2003; 3(10): 611-23. doi: 10.1016/s14733099(03)00770-9.

76. Hirsch HH. Polyomavirus BK nephropathy: a (relemerging complication in renal transplantation.
Am J Transplant. 2002; 2(1): 25-30. doi: 10.1034/j.1600-6143.2002.020106.x.

77. Gardner SD, MacKenzie EF, Smith C, et al. Prospective study of the human polyomaviruses BK and $\mathrm{JC}$ and cytomegalovirus in renal transplant recipients. J Clin Pathol. 1984; 37(5): 578-86. doi: 10.1136/jcp.37.5.578.

78. Padgett BL, Walker DL. Prevalence of antibodies in human sera against JC virus, an isolate from a case of progressive multifocal leukoencephalopathy. J Infect Dis. 1973; 127(4): 467-70. doi: 10.1093/infdis/127.4.467.

79. Jasim HR. A study of viral load of HHV-6 DNA in samples of Iraqi patients during the first year after kidney transplantation. College of Medicine, AlNahrain University, Iraq; 2015.

80. Gai M, Lanfranco G, Segoloni GP. "Decoy cells" in urine. Transplant Proc. 2005; 37(10): 4309-10. doi: 10.1016/j.transproceed.2005.11.045.

81. Mengelle C, Kamar N, Mansuy JM, et al. JC virus DNA in the peripheral blood of renal transplant patients: a 1-year prospective follow-up in France. J Med Virol. 2011; 83(1): 132-6. doi: 10.1002/jmv.21951.

82. Awadalla $Y$, Randhawa $P$, Ruppert $K$, et al. HLA mismatching increases the risk of $B K$ virus nephropathy in renal transplant recipients. Am J Transplant. 2004; 4(10): 1691-6. doi: 10.1111/j.1600-6143.2004.00563.x.

83. Kitamura T, Yogo Y, Kunitake T, Suzuki K, Tajima A, Kawabe K. Effect of immunosuppression on the urinary excretion of BK and JC polyomaviruses in renal allograft recipients. Int J Urol. 1994; 1(1): 2832. doi: 10.1111/j.1442-2042.1994.tb00004.x.

84. Jasim MB, Al-Saedi AJH, Hussein MR, et al. High prevalence of John Cunningham viruria in renal transplant recipients. Iraqi J Med Sci. 2017; 15(2): 108-15.

85. Yin WY, Lu MC, Lee $M C$, et al. A correlation between polyomavirus JC virus quantification and genotypes in renal transplantation. Am J Surg. 2010; 200(1): 53-8. doi: 10.1016/j.amjsurg.2009.03.017.

86. Delbue $S$, Ferraresso $M$, Ghio $L$, et al. A review on JC virus infection in kidney transplant recipients. Clin Dev Immunol. 2013; 2013: 926391. doi: 10.1155/2013/926391.

87. Kusne $S$, Vilchez RA, Zanwar $P$, et al. Polyomavirus JC urinary shedding in kidney and liver transplant recipients associated with reduced creatinine clearance. J Infect Dis. 2012; 206(6): 875-80. doi: 10.1093/infdis/jis469.

88. Kijpittayarit S, Razonable RR. JC Virus Infection After Transplantation: Beyond the Classic Progressive Multifocal Leukoencephalopathy? Gastroenterol Hepatol (N Y). 2007; 3(1): 74-6. 
89. Taheri S, Kafilzadeh F, Shafa M, et al. Comparison of polyomavirus (BK virus and JC viruses) viruria in renal transplant recipients with and without kidney dysfunction. J Res Med Sci. 2011; 16(7): 916-22.

90. Al-Obaidi AB, Kadhim HS, Shamran HA. Detection of BK polyomavirus using real time pcr and urine cytology in 99 renal transplant recipients. J Int Acad Res Multidiscip. 2015; 3(1): 131-41.

91. Ramos E, Drachenberg CB, Papadimitriou JC, et al. Clinical course of polyoma virus nephropathy in 67 renal transplant patients. J Am Soc Nephrol. 2002; 13(8): 2145-51. doi: 10.1097/01.asn.0000023435.07320.81.

92. Ramos $E$, Drachenberg CB, Portocarrero $M$, et al. BK virus nephropathy diagnosis and treatment: experience at the University of Maryland Renal Transplant Program. Clin Transpl. 2002: 143-53.

93. $\mathrm{Hu} J \mathrm{H}$, Zhao $\mathrm{H}$, Huang YP, et al. Opportunistic posttransplantation virus infections in renal transplant recipients. Transplant Proc. 2011; 43(10): 3715-9. doi: 10.1016/j.transproceed.2011.07.024.

94. Sachdeva MS, Nada $R$, Jha $V$, et al. The high incidence of $\mathrm{BK}$ polyoma virus infection among renal transplant recipients in India. Transplantation. 2004; 77(3): 429-31. doi: 10.1097/01.TP.0000113163.02039.30.

95. Brennan DC, Agha I, Bohl DL, et al. Incidence of BK with tacrolimus versus cyclosporine and impact of preemptive immunosuppression reduction. Am J Transplant. 2005; 5(3): 582-94. doi: 10.1111/j.16006143.2005.00742.x.

96. Rossi C, Delforge ML, Jacobs F, et al. Fatal primary infection due to human herpesvirus 6 variant $A$ in a renal transplant recipient. Transplantation. 2001; 71(2): 288-92. doi: 10.1097/00007890-20010127000021.

97. Hyun $H$, Park $E$, Cho $M$, et al. Post-transplant lymphoproliferative diseases in pediatric kidney allograft recipients with Epstein-barr virus viremia. J Korean Med Sci. 2019; 34(30): e203. doi: 10.3346/jkms.2019.34.e203.

98. Yamanishi K, Okuno T, Shiraki K, et al. Identification of human herpesvirus- 6 as a causal agent for exanthem subitum. Lancet. 1988; 1(8594): 1065-7. doi: 10.1016/s0140-6736(88)91893-4.

99. Biberfeld P, Kramarsky B, Salahuddin SZ, et al. Ultrastructural characterization of a new human $B$ lymphotropic DNA virus (human herpesvirus 6) isolated from patients with lymphoproliferative disease. J Natl Cancer Inst. 1987; 79(5): 933-41.

100. Asano $Y$, Yoshikawa $T$, Suga $S$, et al. Clinical features of infants with primary human herpesvirus 6 infection (exanthem subitum, roseola infantum). Pediatrics. 1994; 93(1): 104-8.

101. Hall $C B$, Long $C E$, Schnabel $K C$, et al. Human herpesvirus- 6 infection in children. A prospective study of complications and reactivation. N Engl J Med. 1994; 331(7): 432-8. doi: 10.1056/NEJM199408183310703.

102. De Bolle L, Naesens L, De Clercq E. Update on human herpesvirus 6 biology, clinical features, and therapy. Clin Microbiol Rev. 2005; 18(1): 21745. doi: 10.1128/CMR.18.1.217-245.2005.

103. Okuno T, Takahashi $K$, Balachandra $K$, et al. Seroepidemiology of human herpesvirus 6 infection in normal children and adults. J Clin Microbiol. 1989; 27(4): 651-3. doi: 10.1128/JCM.27.4.651-653.1989.

104. Jarrett RF, Clark DA, Josephs SF, et al. Detection of human herpesvirus-6 DNA in peripheral blood and saliva. J Med Virol. 1990; 32(1): 73-6. doi: 10.1002/jmv.1890320113.

105. Ljungman $P$, Singh $N$. Human herpesvirus- 6 infection in solid organ and stem cell transplant recipients. J Clin Virol. 2006; 37 Suppl 1: S87-91. doi: 10.1016/S1386-6532(06)70018-X.

106. Morris DJ, Littler E, Arrand JR, et al. Human herpesvirus 6 infection in renal-transplant recipients. N Engl J Med. 1989; 320(23): 1560-1.

107. Okuno T, Higashi K, Shiraki K, et al. Human herpesvirus 6 infection in renal transplantation. Transplantation. 1990; 49(3): 519-22. doi: 10.1097/00007890-199003000-00009.

108. Merlino C, Giacchino F, Segoloni GP, et al. Human herpesvirus- 6 infection and renal transplantation. Transplantation. 1992; 53(6): 1382-3. doi: 10.1097/00007890-199206000-00047.

109. Yoshikawa $T$, Suga $S$, Asano $Y$, et al. A prospective study of human herpesvirus- 6 infection in renal transplantation. Transplantation. 1992; 54(5): 879-83. doi: 10.1097/00007890-19921100000022.

110. Herbein G, Strasswimmer J, Altieri $M$, et al. Longitudinal study of human herpesvirus 6 infection in organ transplant recipients. Clin Infect Dis. 1996; 22(1): 171-3. doi: 10.1093/clinids/22.1.171.

111. Kikuta $\mathrm{H}$, Itami $\mathrm{N}$, Matsumoto $\mathrm{S}$, et al. Frequent detection of human herpesvirus 6 DNA in peripheral blood mononuclear cells from kidney transplant patients. J Infect Dis. 1991; 163(4): 925. doi: 10.1093/infdis/163.4.925.

112. Hoshino $K$, Nishi $T$, Adachi $H$, et al. Human herpesvirus-6 infection in renal allografts: retrospective immunohistochemical study in Japanese recipients. Transpl Int. 1995; 8(3): 16973. doi: 10.1007/BF00336532.

113. Lautenschlager I, Razonable RR. Human herpesvirus- 6 infections in kidney, liver, lung, and heart transplantation: review. Transpl Int. 2012; 25(5): 493-502. doi: 10.1111/j.14322277.2012.01443.x. 
114. Agut $H$, Bonnafous $P$, Gautheret-Dejean A. Laboratory and clinical aspects of human herpesvirus 6 infections. Clin Microbiol Rev. 2015; 28(2): 313-35. doi: 10.1128/CMR.00122-14.

115. de Pagter PJ, Schuurman R, Visscher $H$, et al. Human herpes virus 6 plasma DNA positivity after hematopoietic stem cell transplantation in children: an important risk factor for clinical outcome. Biol Blood Marrow Transplant. 2008; 14(7): 831-9. doi: 10.1016/j.bbmt.2008.04.016.

116. Luiz $\mathrm{CR}$, Machado $\mathrm{CM}$, Canto $\mathrm{CL}$, et al. Monitoring for HHV-6 infection after renal transplantation: evaluation of risk factors for sustained viral replication. Transplantation. 2013; 95(6): 842-6. doi: 10.1097/TP.0b013e3182807ab7.

117. Al-Obaidi A, Shamran HA, Abdlameer AS, et al. Occurrence and risk factors of human herpes virus-6 among renal transplant recipients: A single-center study. J Pharm Sci Res. 2018; 10: 1098-102.

118. Jacobs F, Knoop C, Brancart F, et al. Human herpesvirus- 6 infection after lung and heart-lung transplantation: a prospective longitudinal study. Transplantation. 2003; 75(12): 1996-2001. doi: 10.1097/01.TP.0000058809.42027.66.

119. Frenkel $N$, Schirmer EC, Wyatt $L S$, et al. Isolation of a new herpesvirus from human CD4+ T cells. Proc Natl Acad Sci U S A. 1990; 87(2): 748-52. doi: 10.1073/pnas.87.2.748.

120. Wyatt LS, Rodriguez WJ, Balachandran $\mathrm{N}$, et al. Human herpesvirus 7: antigenic properties and prevalence in children and adults. J Virol. 1991; 65(11): 6260-5. doi: 10.1128/JVI.65.11.62606265.1991.

121. Yamanishi K. Human herpesvirus 6 and human herpesvirus 7. In: Knipe DM, Howley PM, Fields virology. 4th ed. Philadelphia (PA): Lippincott Williams \& Wilkins; 2001. p. 2785-801.

122. Mendez JC, Dockrell DH, Espy MJ, et al. Human beta-herpesvirus interactions in solid organ transplant recipients. J Infect Dis. 2001; 183(2): 179-84. doi: 10.1086/317929.

123. Osman HK, Peiris JS, Taylor CE, et al. Correlation between the detection of viral DNA by the polymerase chain reaction in peripheral blood leukocytes and serological responses to human herpesvirus 6, human herpesvirus 7, and cytomegalovirus in renal allograft recipients. J Med Virol. 1997; 53(3): 288-94. doi: 10.1002/(sici)1096-9071(199711)53:3<288::aidjmv19>3.0.co;2-d.

124. Osman HK, Peiris JS, Taylor CE, et al. "Cytomegalovirus disease" in renal allograft recipients: is human herpesvirus 7 a co-factor for disease progression? J Med Virol. 1996; 48(4): 295-301. doi: 10.1002/(SICI)10969071(199604)48:4<295::AID-JMV1>3.0.CO;2-2.
125. Griffiths PD, Ait-Khaled $M$, Bearcroft $C P$, et al. Human herpesviruses 6 and 7 as potential pathogens after liver transplant: prospective comparison with the effect of cytomegalovirus. J Med Virol. 1999; 59(4): 496-501. doi: 10.1002/(sici)1096-9071(199912)59:4<496::aidjmv12>3.0.co;2-u.

126. Ratnamohan VM, Chapman J, Howse $H$, et al. Cytomegalovirus and human herpesvirus 6 both cause viral disease after renal transplantation. Transplantation. 1998; 66(7) :877-82. doi: 10.1097/00007890-199810150-00011.

127. Singh N, Carrigan DR, Gayowski T, et al. Human herpesvirus-6 infection in liver transplant recipients: documentation of pathogenicity. Transplantation. 1997; 64(5): 674-8. doi: 10.1097/00007890-199709150-00002.

128. Chan PK, Peiris JS, Yuen KY, et al. Human herpesvirus- 6 and human herpesvirus- 7 infections in bone marrow transplant recipients. J Med Virol. 1997; 53(3): 295-305. doi: 10.1002/(sici)1096-9071(199711)53:3<295::aidjmv20>3.0.co;2-f.

129. Kidd IM, Clark DA, Sabin CA, et al. Prospective study of human beta herpes viruses after renal transplantation: association of human herpes virus 7 and cytomegalovirus co-infection with cytomegalovirus disease and increased rejection. Transplantation. 2000; 69(11): 2400-4. doi: 10.1097/00007890-200006150-00032.

130. Singh N. Human herpesviruses- $6,-7$ and -8 in organ transplant recipients. Clin Microbiol Infect. 2000; 6(9): 453-9. doi: 10.1046/j.14690691.2000.00129.x.

131. Margolius LP. Kaposi's sarcoma and other malignancies in renal transplant recipients. Transplant Rev. 1996; 10: 129-37.

132. Aebischer MC, Zala LB, Braathen LR. Kaposi's sarcoma as manifestation of immunosuppression in organ transplant recipients. Dermatology. 1997; 195(1): 91-2. doi: 10.1159/000245703.

133. Montagnino G, Bencini PL, Tarantino A, et al. Clinical features and course of Kaposi's sarcoma in kidney transplant patients: report of 13 cases. Am J Nephrol. 1994; 14(2): 121-6. doi: 10.1159/000168700.

134. Moosa MR, Treurnicht FK, van Rensburg EJ, et al. Detection and subtyping of human herpesvirus- 8 in renal transplant patients before and after remission of Kaposi's sarcoma. Transplantation. 1998; 66(2): 214-8. doi: 10.1097/00007890199807270-00013.

135. Nagy S, Gyulai R, Kemeny L, et al. Iatrogenic Kaposi's sarcoma: HHV8 positivity persists but the tumors regress almost completely without immunosuppressive therapy. Transplantation. 
2000; 69(10): 2230-1. doi: 10.1097/00007890$200005270-00053$.

136. Francès $C$, Mouquet $C$, Marcelin $A G$, et al. Outcome of kidney transplant recipients with previous human herpesvirus- 8 infection. Transplantation. 2000; 69(9): 1776-9. doi: 10.1097/00007890-200005150-00008.

137. Luppi M, Barozzi $P$, Santagostino $G$, et al. Molecular evidence of organ-related transmission of Kaposi sarcoma-associated herpes virus or human herpesvirus-8 in transplant patients. Blood. 2000; 96(9): 3279-81.

138. Jenkins FJ, Hoffman LJ, Liegey-Dougall $A$. Reactivation of and primary infection with human herpesvirus 8 among solid-organ transplant recipients. J Infect Dis. 2002; 185(9): 1238-43. doi: $10.1086 / 340237$.

139. Euvrard S, Kanitakis J, Claudy A. Skin cancers after organ transplantation. N Engl J Med. 2003; 348(17): 1681-91. doi: 10.1056/NEJMra022137.

140. Raedemaeker J, Marot L, Camboni A, et al. Kaposi sarcoma after kidney transplantation. BMJ Case Rep. 2019; 12(5): e229681. doi: 10.1136/bcr2019-229681.

141. Rodriguez-Moreno A, Sanchez-Fructuoso Al, Calvo $\mathrm{N}$, et al. Varicella infection in adult renal allograft recipients: experience at one center. Transplant Proc. 2006; 38(8): 2416-8. doi: 10.1016/j.transproceed.2006.08.060.

142. Arness $T$, Pedersen $R$, Dierkhising $R$, et al. Varicella zoster virus-associated disease in adult kidney transplant recipients: incidence and riskfactor analysis. Transpl Infect Dis. 2008; 10(4): 260-8. doi: 10.1111/j.1399-3062.2007.00289.x.

143. Gourishankar S, McDermid JC, Jhangri GS, et al. Herpes zoster infection following solid organ transplantation: incidence, risk factors and outcomes in the current immunosuppressive era. Am J Transplant. 2004; 4(1):108-15. doi: 10.1046/j.1600-6143.2003.00287.x.

144. Pergam SA, Limaye AP; AST Infectious Diseases Community of Practice. Varicella zoster virus in solid organ transplantation. Am J Transplant. 2013; 13 Suppl 4(Suppl 4): 138-46. doi: 10.1111/ajt.12107.

145. Lauzurica R, Bayés $B$, Frías $C$, et al. Disseminated varicella infection in adult renal allograft recipients: role of mycophenolate mofetil. Transplant Proc. 2003; 35(5): 1758-9. doi: 10.1016/s0041-1345(03)00684-5.

146. Kusne S, Pappo O, Manez R, et al. Varicella-zoster virus hepatitis and a suggested management plan for prevention of VZV infection in adult liver transplant recipients. Transplantation. 1995; 60(6): 619-21. doi: 10.1097/00007890$199509270-00019$.
147. Mustapic Z, Basic-Jukic N, Kes P, et al. Varicella zoster infection in renal transplant recipients: prevalence, complications and outcome. Kidney Blood Press Res. 2011; 34(6): 382-6. doi: 10.1159/000328730.

148. Pergam SA, Forsberg CW, Boeckh MJ, et al. Herpes zoster incidence in a multicenter cohort of solid organ transplant recipients. Transpl Infect Dis. 2011; 13(1): 15-23. doi: 10.1111/j.13993062.2010.00547.x.

149. Manuel O, Kumar D, Singer LG, et al. Incidence and clinical characteristics of herpes zoster after lung transplantation. J Heart Lung Transplant. 2008; 27(1): 11-6. doi: 10.1016/j.healun.2007.09.028.

150. Ko GB, Kim T, Kim SH, et al. Increased incidence of herpes zoster in the setting of cytomegalovirus preemptive therapy after kidney transplantation. Transpl Infect Dis. 2013; 15(4): 416-23. doi: 10.1111/tid.12091.

151. Studahl M, Petzold M, Cassel T. Disease burden of herpes zoster in Sweden--predominance in the elderly and in women - a register-based study. BMC Infect Dis. 2013; 13: 586. doi: 10.1186/14712334-13-586.

152. Fishman JA. Infection in solid-organ transplant recipients. N Engl J Med. 2007; 357(25): 2601-14. doi: 10.1056/NEJMra064928.

153. Fehr T, Bossart W, Wahl C, et al. Disseminated varicella infection in adult renal allograft recipients: four cases and a review of the literature. Transplantation. 2002; 73(4): 608-11. doi: 10.1097/00007890-200202270-00023.

154. Gnann JW. Other herpes viruses: Herpes simplex virus, varicella-zoster virus, human herpes virus types 6, 7 and 8. In: Bowden RA, Per Ljungman P, Snydman DR (eds). Transplant Infections. $1^{\text {st }}$ ed. Lippincott-Raven: Philadelphia; 1998. p. 265-86.

155. Herrero JI, Quiroga J, Sangro B, Pardo F, Rotellar F, Alvarez-Cienfuegos J, Prieto J. Herpes zoster after liver transplantation: incidence, risk factors, and complications. Liver Transpl. 2004; 10(9): 1140-3. doi: 10.1002/lt.20219.

156. Huang $\mathrm{GH}, \mathrm{Xu}$ WB. [Recent advance in new types of human adenovirus]. Bing Du Xue Bao. 2013; 29(3): 342-8. Chinese.

157. Echavarría M. Adenoviruses in immunocompromised hosts. Clin Microbiol Rev. 2008; 21(4): 704-15. doi: 10.1128/CMR.00052-07.

158. Singh G, Robinson CM, Dehghan $S$, et al. Homologous recombination in E3 genes of human adenovirus species D. J Virol. 2013; 87(22): 12481-8. doi: 10.1128/JVI.01927-13.

159. Ison MG. Adenovirus infections in transplant recipients. Clin Infect Dis. 2006; 43(3): 331-9. doi: $10.1086 / 505498$. 
160. Wigand R. Re: "the Seattle Virus Watch. VII. Observations of adenovirus infections". Am J Epidemiol. 1978; 107(4): 352-3. doi: 10.1093/oxfordjournals.aje.a112551.

161. Humar A, Kumar D, Mazzulli $T$, et al. A surveillance study of adenovirus infection in adult solid organ transplant recipients. Am J Transplant. 2005; 5(10): 2555-9. doi: 10.1111/j.16006143.2005.01033.x.

162. Robinson CM, Singh G, Lee JY, et al. Molecular evolution of human adenoviruses. Sci Rep. 2013; 3: 1812. doi: 10.1038/srep01812.

163. Schechter T, Gassas A, Weitzman S, et al. Hematopoietic stem-cell transplantation following solid-organ transplantation in children. Bone Marrow Transplant. 2011; 46(10): 1321-5. doi: 10.1038/bmt.2011.153.

164. Institut national d'excellenceen santé eten services sociaux (INESSS). Quantitative Real-Time PCR for Detection of Adenovirus in Immunosuppressed Patients. (Reference 2013.03.008) Notice of Assessment. 2014.

165. Lion T. Adenovirus infections in immunocompetent and immunocompromised patients. Clin Microbiol Rev. 2014; 27(3): 441-62. doi: 10.1128/CMR.00116-13.

166. Watcharananan SP, Avery $R$, Ingsathit $A$, et al. Adenovirus disease after kidney transplantation: course of infection and outcome in relation to blood viral load and immune recovery. Am J Transplant. 2011; 11(6): 1308-14. doi: 10.1111/j.1600-6143.2011.03479.x.

167. Kapila K, Nampoory MR, Johny KV, et al. Role of urinary cytology in detecting human polyoma bk virus in kidney transplant recipients. A preliminary report. Med Princ Pract. 2007; 16(3): 237-9. doi: 10.1159/000100398.

168. Boldorini R, Brustia $M$, Veggiani $C$, et al. Periodic assessment of urine and serum by cytology and molecular biology as a diagnostic tool for BK virus nephropathy in renal transplant patients. Acta Cytol. 2005; 49(3): 235-43. doi: 10.1159/000326143.

169. 169. Ahmed HM, Al-Obaidi AB, Hussein MR, et al. adenovirus infection in a sample of iraqi kidney transplant recipients: molecular and hematological study. Iraqi J Med Sci. 2018; 16(3) :279-88. doi: 10.22578/IJMS.16.3.7.

170. Kampmann B, Cubitt D, Walls $T$, et al. Improved outcome for children with disseminated adenoviral infection following allogeneic stem cell transplantation. Br J Haematol. 2005; 130(4): 595603. doi: 10.1111/j.1365-2141.2005.05649.x.

171. Rubin RH, Kemmerly SA, Conti D, et al. Prevention of primary cytomegalovirus disease in organ transplant recipients with oral ganciclovir or oral acyclovir prophylaxis. Transpl Infect Dis. 2000; 2(3): 112-7.

172. Barraclough K, Oliver K, Playford EG, Preston J, et al. Life-threatening adenovirus infection in a kidney transplant recipient. NDT Plus. 2009; 2(3): 250-3. doi: 10.1093/ndtplus/sfp003.

\section{Correspondence to Dr. Asmaa B. Al-Obaidi E-mail: asmaa.viro@gmail.com, asmaa.viro@ced.nahrainuniv.edu.iq}

